\title{
The relationship to age and cerebral vascular accidents of fibrin and fibrinolytic activity
}

\author{
R. HUME ${ }^{1}$
}

From the Southern General Hospital, Glasgow

SYNOPSIS Three 'normal' groups of people-young, middle-aged, and old-have been investigated with regard to the fibrin content and fibrinolytic activity of the blood. The fourth group consisted of middle-aged people who had previously sustained a cerebral vascular accident matched statistically for age with the middle-aged normals. It was concluded that fibrin increases with age but there is an interaction between age and sex, the female having a higher level in the young group and the male a higher level in the middle-aged group. There was no sex difference in the levels of fibrin in the old age group. Fibrinolytic activity increases with age and there is a positive correlation between fibrin and fibrinolytic activity but no age-sex interaction. Those with cerebral vascular accidents tended to have higher fibrin levels and lower fibrinolytic activity but the differences were not statistically significant. There did, however, appear to be an increase in antifibrinolytic activity in the cerebral vascular group.

There is in blood an enzyme system which is capable of digesting fibrin, and this property of blood is called fibrinolytic activity. Although a vast literature has gathered on the biochemical investigation of the component parts of this system, less attention has been paid to relating fibrinolytic activity to vascular disease.

An increase in antifibrinolytic activity has been found in certain cases of myocardial infarction (Guest, Daly, Ware, and Seegers, 1948) and correspondingly fibrinolytic activity has been found to be depressed (Hume, 1958a; Røjel, 1959). Intermittent claudication (Nestel, 1959) and arteriosclerosis in general have been reported to be associated with depressed fibrinolytic activity (Janiakowa, KotlarekHaus, Potoczek, and Tkaczewski, 1958).

As there is a possible relationship between fibrin formation and vascular disease, and since there is an increase in vascular disease with age, it seemed of interest to determine whether fibrinolytic activity varied with age and whether people with cerebral vascular accidents occurring in middle life differed from normal controls in this respect. In the process of this pilot study it was found that there were differences in the fibrin levels and these observations are also reported.

\footnotetext{
Received for publication 8 September 1960.
}

'Present address: Western Infirmary, Glasgow.

\section{MATERIALS AND METHODS}

PATIENTS Group I consisted of 20 (seven men and 13 women) young healthy medical students and nurses whose ages ranged from 19 to 30 years.

Group II (10 men and 10 women) consisted of 10 healthy members of the hospital staff and 10 patients attending the Department of Psychological Medicine with minor psychiatric disturbances but not thought to have any organic or vascular disease. Their ages ranged from 40 to 65 years. Although not intensively studied to exclude occult vascular disease, it was felt that for a pilot study they were reasonably normal in this respect.

Group III consisted of 20 (four men and 16 women) old people whose ages ranged from 75 to 92 years. Their admission to hospital was for the following reasons: eight were social problems, seven had had a small cerebral episode resulting in weakness of one side, one had mild iron deficiency anaemia with urinary infection, one had glycosuria (no treatment required), one had mitral stenosis with cerebral embolus, one had leg pains of a vague nature, and one had diverticulosis. It was felt that although all had some evidence of arteriosclerosis, they differed from the 'normal' population in longevity, namely $67 \cdot 3$ years for males and $72 \cdot 1$ years for females at 1 year of age (Registrar-General for Scotland, 1960), and because of the mere fact of survival were likely to differ from people dying in middle life from vascular disease. No attempt was made to eliminate all the occult diseases to which the aged may well fall heir, e.g., osteroporosis, chronic renal insufficiency, etc. 
TABLE I

COMPOSITION OF GROUPS

Group I: Young Normals $\begin{aligned} \text { No. Age Sex } & \begin{array}{l}\text { Total Lysis } \\ \text { Fibrin in 1 } \\ (\mathrm{mg} . \%) \text { Hour }\end{array}\end{aligned}$

\begin{tabular}{lllllllll}
\hline 1 & 30 & $M$ & 291 & 52 & 1 & 40 & $M$ & 309
\end{tabular}

$227 \quad M \quad 202$

$\begin{array}{llll}3 & 21 & M & 189\end{array}$

$\begin{array}{llll}4 & 25 & M & 231 \\ 5 & 25 & M & 167\end{array}$

$\begin{array}{llll}6 & 29 & M & 232\end{array}$

$\begin{array}{llll}7 & 24 & M & 193\end{array}$

$\begin{array}{llll}8 & 23 & F & 180\end{array}$

$\begin{array}{rrrr}9 & 20 & F & 347\end{array}$

$10 \quad 19 \quad$ F $\quad 270$

$\begin{array}{llll}11 & 19 & F & 212\end{array}$

$\begin{array}{llll}12 & 21 & F & 218\end{array}$

$\begin{array}{llll}13 & 25 & \text { F } & 257\end{array}$

$\begin{array}{llll}14 & 28 & F & 360\end{array}$

$\begin{array}{llll}15 & 24 & \text { F } & 296\end{array}$

$\begin{array}{llll}16 & 24 & F & 218\end{array}$

$\begin{array}{llll}17 & 22 & \text { F } & 296\end{array}$

$\begin{array}{llll}18 & 23 & \text { F } & 335\end{array}$

$\begin{array}{llll}19 & 23 & \text { F } & 386 \\ 20 & 25 & \text { F } & 193\end{array}$
Group II: Middle-aged Normals

$\begin{array}{llll}2 & 48 & M & 270\end{array}$

$\begin{array}{llll}3 & 50 & M & 218\end{array}$

$\begin{array}{llll}4 & 44 & F & 245\end{array}$

$\begin{array}{llll}5 & 48 & F & 180\end{array}$

$\begin{array}{llll}6 & 46 & F & 193\end{array}$

$\begin{array}{llll}7 & 53 & F & 296\end{array}$

$8 \quad 53 \quad M \quad 463$

$\begin{array}{llll}9 & 60 & M & 373\end{array}$

$\begin{array}{llll}10 & 50 & F & 296\end{array}$

11 54 $M \quad 360$

$\begin{array}{llll}12 & 58 & M & 386\end{array}$

$1361 \quad F \quad 218$

$\begin{array}{llll}14 & 47 & F & 218\end{array}$

$\begin{array}{llll}15 & 47 & F & 180\end{array}$

$\begin{array}{llll}16 & 64 & F & 502\end{array}$

$\begin{array}{llll}17 & 55 & F & 245\end{array}$

$18 \quad 58 \quad M \quad 605$

$\begin{array}{llll}19 & 65 & M & 463\end{array}$

$\begin{array}{llll}20 & 58 & M & 309\end{array}$
Normals

Group IV consisted of 20 patients (11 men and nine women) whose ages ranged from 32 to 65 years and who had sustained a cerebral catastrophe resulting in hemiparesis or hemiplegia. Cerebral embolism was excluded as far as was possible but it was not possible to be certain whether cerebral thrombosis or haemorrhage had been the cause. Such an accident, however, was taken to indicate cerebral vascular disease. The illness had been established between five months and eight years with the exception of two patients who had developed paralysis three weeks previously. No patient was included whose cerebral vascular accident was of recent onset because it had been noted on two occasions that the fibrin levels were very high a few days after the incident, falling to normal levels in two weeks or so. A similar phenomenon has been reported after acute myocardial infarction (Gilchrist and Tulloch, 1952; Losner, Volk, and Wilensky, 1954) and it appears to be a usual occurrence after a variety of insults including surgical, chemical, and physical injuries as well as infections (Cohen, 1953).

Fibrinolytic activity was measured by the method of partial lysis previously described (Hume, 1958b). Briefly this involves measuring the amount of fibrin digested in a given period of time. Equal amounts of diluted plasma are added to test-tubes in a water-bath at $37^{\circ} \mathrm{C}$. and clotted with thrombin. The amount of fibrin present after incubating for half an hour is taken as the initial level, and the difference in the fibrin content of the remaining tubes, estimated at hourly intervals, is a measure of the fibrinolytic activity. The method employed for estimating fibrin is a colorimetric one (Ratnoff and Menzies adapted by Holborn, 1951) and the results expressed as milligrams of fibrin per $100 \mathrm{ml}$. A low temperature technique was not employed. The blood was collected into graduated centrifuge tubes at room temperature and immediately spun in a M.S.E. super minor centrifuge at 4,500 r.p.m. for five minutes. The
Group III: Old Age

$\begin{array}{ll}\text { No. Age Sex } & \text { Total Lysis } \\ & \text { Fibrin in 1 }\end{array}$

Group IV: Middle-aged Cerebral Cases (mg. \%) Hour

No. Age Sex Total Lysis Lysi 흔 Fibrin in 1 in $2 \frac{1}{\supset}$ (mg. \%) Hour Hou零

$\begin{array}{rlll}1 & 85 & \text { F } & 379 \\ 2 & 80 & \text { F } & 515 \\ 3 & 79 & \text { M } & 180 \\ \mathbf{4} & \mathbf{8 4} & \text { F } & 322 \\ 5 & 87 & \text { F } & 309 \\ 6 & 84 & \text { F } & 206 \\ 7 & 79 & \text { F } & 245 \\ 8 & 78 & \text { F } & 329 \\ 9 & 75 & \text { F } & 322 \\ 10 & \mathbf{7 8} & \text { F } & 386 \\ 11 & 76 & \text { M } & 202 \\ 12 & \mathbf{9 2} & \text { M } & 399 \\ 13 & 87 & \text { F } & 270 \\ 14 & 82 & \text { M } & 450 \\ 15 & 82 & \text { F } & 386 \\ 16 & 85 & \text { F } & 438 \\ 17 & 85 & \text { F } & 386 \\ 18 & \mathbf{8 1} & \text { F } & \mathbf{4 3 8} \\ 19 & 81 & \text { F } & 309 \\ 20 & \mathbf{7 9} & \text { F } & \mathbf{4 8 2}\end{array}$

tubes were prepared and set up for incubation within $10^{\circ}$ minutes after withdrawal of blood. The estimationg were made between 1.30 p.m. and 2.15 p.m. in order to try and standardize the technique with regard to the effect of diet (Greig and Runde, 1957) and diurna fluctuation (Buckell and Elliott, 1959).

RESULTS

AGE From a consideration of the ages in terms of groups (Tables I and II) it can be seen that there.

TABLE II

MEAN AGE GROUPS STUDIED

\begin{tabular}{|c|c|c|c|c|c|c|}
\hline \multirow[t]{2}{*}{ Group } & \multicolumn{3}{|l|}{ Male } & \multicolumn{3}{|l|}{ Female } \\
\hline & $\begin{array}{l}\text { No. of } \\
\text { Cases }\end{array}$ & $\begin{array}{l}\text { Mean } \\
\text { Age }\end{array}$ & S.D. & $\begin{array}{l}\text { No. of } \\
\text { Cases }\end{array}$ & $\begin{array}{l}\text { Mean } \\
\text { Age }\end{array}$ & S.L \\
\hline I & 7 & 25.9 & 2.4 & 13 & $22 \cdot 8$ & $1 \cdot 8$ \\
\hline II & 10 & $54 \cdot 4$ & $6 \cdot 73$ & 10 & $51 \cdot 5$ & $6 \cdot 38$ \\
\hline III & 4 & $82 \cdot 3$ & $5 \cdot 3$ & 16 & 81.9 & $2 \cdot 8$ \\
\hline IV & 11 & $51 \cdot 5$ & $8 \cdot 4$ & 9 & 56.8 & 4.9 \\
\hline
\end{tabular}

is no statistical difference between groups II and IV that is, the middle aged controls and the middle aged cerebral cases, nor is there any difference between the sexes in any group with regard to age, with thळ exception of group I where the sex difference is statistically significant $(P<0.01)$.

FIBRIN Analysis of the initial fibrin levels in group I, II, and III (Tables I and III) shows that there is f $^{2}$ positive correlation between age and fibrin levels? for both males and females (M.r. $=+0.49$ F.r. $=0$ 
TABLE III

INITIAL MEAN FIBRIN LEVELS

\begin{tabular}{|c|c|c|c|c|c|c|c|c|c|}
\hline \multirow[t]{2}{*}{ Group } & \multicolumn{3}{|l|}{ Male } & \multicolumn{3}{|l|}{ Female } & \multicolumn{3}{|c|}{ Male and Female } \\
\hline & $\begin{array}{l}\text { No. of } \\
\text { Cases }\end{array}$ & $\begin{array}{l}\text { Mean Fibrin } \\
\text { Level } \\
\text { (mg.\%) }\end{array}$ & S.D. & $\begin{array}{l}\text { No. of } \\
\text { Cases }\end{array}$ & $\begin{array}{l}\text { Mean Fibrin } \\
\text { Level } \\
\text { (mg.\%) }\end{array}$ & S.D. & $\begin{array}{l}\text { No. of } \\
\text { Cases }\end{array}$ & $\begin{array}{l}\text { Mean Fibrin } \\
\text { Level } \\
\text { (mg.\%) }\end{array}$ & S.D. \\
\hline I & 7 & 215 & 37.8 & 13 & 274 & 65.5 & 20 & 254 & 67 \\
\hline II & 10 & 375.6 & 106 & 10 & $257 \cdot 3$ & 91 & 20 & 316 & 115 \\
\hline III & 4 & 307.8 & 118 & 16 & 357.6 & 82 & 20 & 348 & 111 \\
\hline IV & 11 & $325 \cdot 4$ & 110 & 9 & 356 & 110 & 20 & 339 & 111 \\
\hline
\end{tabular}

$+0.47)$. This is illustrated in Fig. 1. However, analysis of variance yielded the fact that there was an interaction between sex and age. This was statistically significant $(P<0.01)$ and is illustrated in Fig. 2. The sex differences analysed separately show that there is probably a significant difference between the means in group $I(P<0.05)$ and similarly in group II $(P<0.05)$. However, the results in group I are statistically suspect in the sex difference because there was a significant difference $(P<0.01)$, as previously noted, between the ages of the males and females in this group. In actual fact, however, the age effect is so slight that the age difference could not explain the sex difference in this group. No significant difference was noted in group III. Although the mean fibrin level is much higher in the middle-aged females in group IV compared with that of the middle-aged females in group II (Table III), the difference between the means is not significant $(P-0 \cdot 1)$. Similarly there is no statistically significant difference between the means of the males in the same two groups.

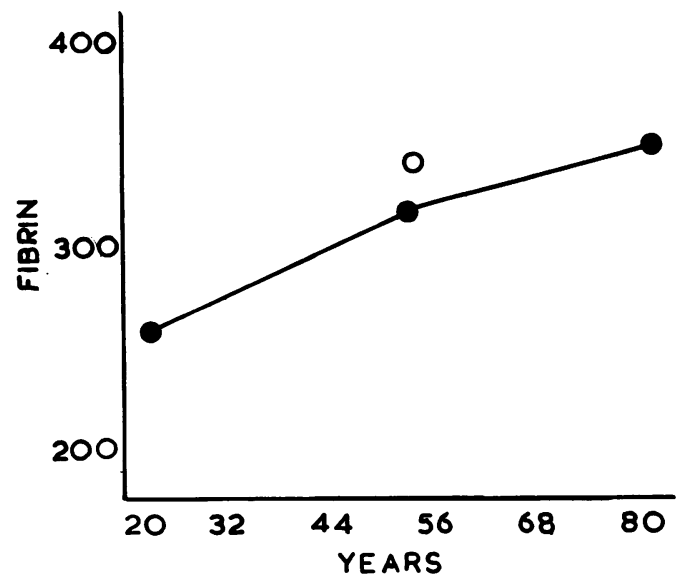

FiG. 1. The mean fibrin levels ( $\mathrm{mg} . \%$ ) for each group reflect an increase with years $(\mathbf{O}=$ mean fibrin level for cerebral cases).
LYSIS When lysis during the first hour is considered for groups I, II, and III (Tables I and IV) it can be seen that there is a positive correlation between age and lysis for both sexes (M.r. $=+0.35$ F.r. $=+0 \cdot 30$ ) illustrated in Fig. 3. Analysis of variance revealed no sex and age interaction (Fig. 4). However, a variance ratio test shows that the difference in the variance between groups I and III is of high statistical significance $(P<0.001)$, and between groups I and II and $I$ and IV to be statistically significant $(P<0.01)$. Analysis of the means revealed no statistically significant difference between the sexes in any group (Table IV), although the males had a higher mean reading and wider variation in group II. Although the mean lysis level is much lower in the middle-aged males in group IV as compared with the lysis level in the middle-aged males of group II, the differences were not statistically significant, nor was there any difference between the females of the same groups.

When lysis during the second hour was compared between groups II and IV (Table IV) again no statistically significant difference in variance or

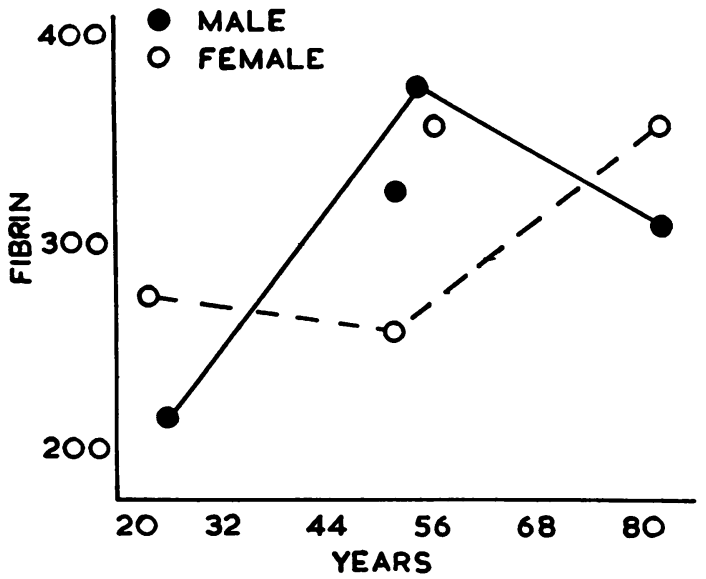

FIG. 2. The mean fibrin levels (mg. \%) for each sex shows an interaction between sex and age $(\mathrm{O}=$ male cerebral cases and $\mathbf{O}=$ female cerebral cases). 

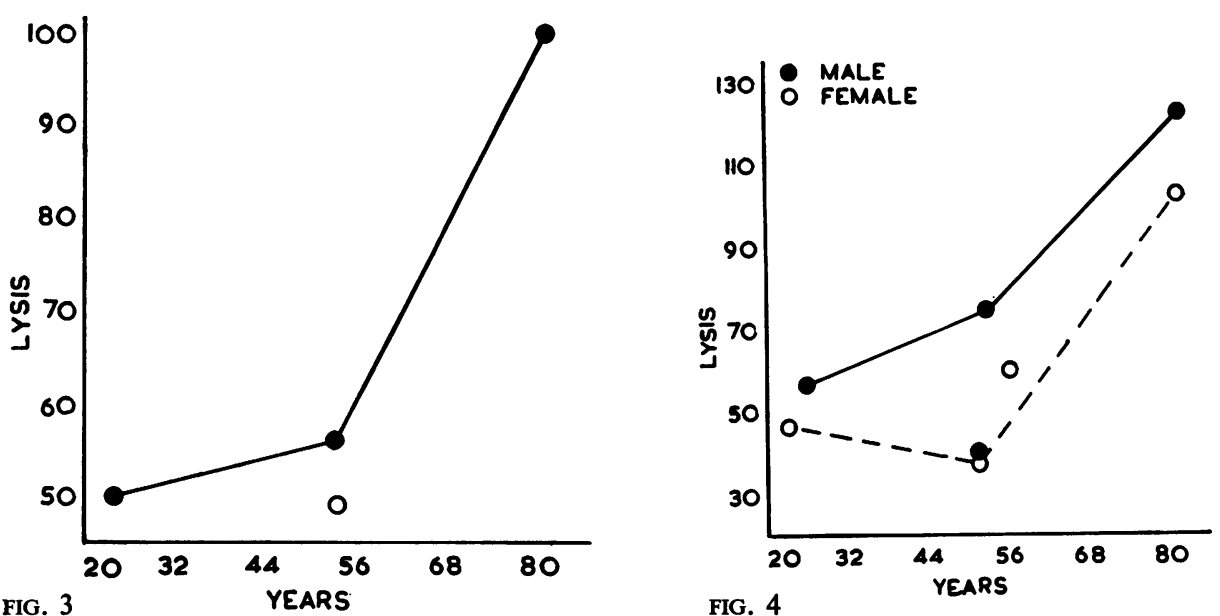

FIG. 3. Mean lysis (mg. fibrin digested \%) for each group reflects an increase with years $(\mathbf{O}=$ mean lysis level for the cerebral cases).

FIG. 4. The mean lysis level (mg. of fibrin digested \%) for each sex shows no sex-age interaction $(\mathbf{O}=$ male cerebral cases, $\mathbf{O}=$ female cerebral cases $)$.

means was detected. However, when the lysis was expressed as a percentage lysis in the second hour compared with the first hour, analysis of variance revealed that the difference between the two groups was probably significant $(P<0.05)$ (Table IV), suggesting the presence of a retarding factor in group IV. The females in both groups showed a lower mean percentage but this was not statistically significant.

Consideration of fibrin levels and lysis together revealed a positive correlation between these two factors for both sexes (M.r. $=+0 \cdot 20$ F.r. $=+0 \cdot 44$ ).

\section{DISCUSSION}

Analysis of the initial fibrin levels in the first three groups reveals the fact that the fibrin content of blood increases with age. However, when the sexeso are analysed separately it can be seen that there is an interaction between age and sex, the femaleo having the higher level in the young age group and the male in the middle-aged group. In the old age group there is no sex difference. This suggests that the ageing process is associated with an increase ing fibrin content of the blood and that it occurs at an-

TABLE IV

MEAN LYSIS LEVELS FOR TWO PERIODS OF STUDY AND PERCENTAGE LYSIS COMPARED FOR EACH PERIOD

\begin{tabular}{|c|c|c|c|c|c|c|c|c|c|}
\hline \multirow[t]{2}{*}{ Group } & \multicolumn{3}{|l|}{ Male } & \multicolumn{3}{|l|}{ Female } & \multicolumn{3}{|c|}{ Male and Female } \\
\hline & $\begin{array}{l}\text { No. of } \\
\text { Cases }\end{array}$ & $\begin{array}{l}\text { Lysis in } \\
\text { First Hour } \\
\text { (mg. \%) }\end{array}$ & S.D. & $\begin{array}{l}\text { No. of } \\
\text { Cases }\end{array}$ & $\begin{array}{l}\text { Lysis in } \\
\text { First Hour } \\
\text { (mg. \%) }\end{array}$ & S.D. & $\begin{array}{l}\text { No. of } \\
\text { Cases }\end{array}$ & $\begin{array}{l}\text { Lysis in } \\
\text { First Hour } \\
\text { (mg.\%) }\end{array}$ & S.D. \\
\hline $\begin{array}{r}\text { I } \\
\text { II } \\
\text { III } \\
\text { IV }\end{array}$ & $\begin{array}{r}7 \\
10 \\
4 \\
11\end{array}$ & $\begin{array}{c}56 \cdot 7 \\
74 \cdot 3 \\
122 \\
39 \cdot 8\end{array}$ & $\begin{array}{c}20 \\
75 \\
161 \\
56.9\end{array}$ & $\begin{array}{r}13 \\
10 \\
16 \\
9\end{array}$ & $\begin{array}{l}46 \cdot 6 \\
37 \cdot 2 \\
95 \cdot 1 \\
60\end{array}$ & $\begin{array}{c}54 \\
52 \\
109 \\
55.8\end{array}$ & $\begin{array}{l}20 \\
20 \\
20 \\
20\end{array}$ & $\begin{array}{r}50 \\
56 \\
100 \\
49\end{array}$ & 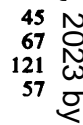 \\
\hline Group & $\begin{array}{l}\text { No. of } \\
\text { Cases }\end{array}$ & $\begin{array}{l}\text { Lysis in } \\
\text { Second Hour } \\
\text { (mg.\%) }\end{array}$ & S.D. & $\begin{array}{l}\text { No. of } \\
\text { Cases }\end{array}$ & $\begin{array}{l}\text { Lysis in } \\
\text { Second Hour } \\
\text { (mg.\%) }\end{array}$ & S.D. & $\begin{array}{l}\text { No. of } \\
\text { Cases }\end{array}$ & $\begin{array}{l}\text { Lysis in } \\
\text { Second Hour } \\
\text { (mg.\%) }\end{array}$ & S.D. $\frac{0}{\mathbb{C}}$ \\
\hline$\underset{\text { IV }}{\text { II }}$ & $\begin{array}{l}10 \\
11\end{array}$ & $\begin{array}{l}149 \cdot 1 \\
158 \cdot 8\end{array}$ & $\begin{array}{l}119 \\
125\end{array}$ & $\begin{array}{r}10 \\
9\end{array}$ & $\begin{array}{l}81 \cdot 1 \\
169\end{array}$ & $\begin{array}{c}73 \cdot 4 \\
155\end{array}$ & $\begin{array}{l}20 \\
20\end{array}$ & $\begin{array}{l}115 \\
163\end{array}$ & 104 윰 \\
\hline Group & $\begin{array}{l}\text { No. of } \\
\text { Cases }\end{array}$ & $\begin{array}{l}\text { Change in } \\
\% \text { Lysis }\end{array}$ & S.D. & $\begin{array}{l}\text { No. of } \\
\text { Cases }\end{array}$ & $\begin{array}{l}\text { Change in } \\
\% \text { Lysis }\end{array}$ & S.D. & $\begin{array}{l}\text { No. of } \\
\text { Cases }\end{array}$ & $\begin{array}{l}\text { Change in } \\
\% \text { Lysis }\end{array}$ & S.D. \\
\hline II & $\begin{array}{l}10 \\
11\end{array}$ & $\begin{array}{l}14 \cdot 3 \\
33 \cdot 4\end{array}$ & $\begin{array}{l}17 \cdot 3 \\
23 \cdot 9\end{array}$ & $\begin{array}{r}10 \\
9\end{array}$ & $\begin{array}{r}9 \cdot 1 \\
18 \cdot 2\end{array}$ & $\begin{array}{l}18 \cdot 7 \\
26 \cdot 7\end{array}$ & $\begin{array}{l}20 \\
20\end{array}$ & $\begin{array}{l}11 \cdot 7 \\
26 \cdot 6\end{array}$ & $\begin{array}{l}18 \cdot 1 \\
26 \cdot 4\end{array}$ \\
\hline
\end{tabular}


earlier age in the male. An increase in fibrin with age has previously been described (Schultz, 1956). It is of interest to speculate on whether the high fibrin levels in middle-aged males contribute to vascular disease in this group, especially in view of the fibrin theory of the genesis of atheroma (Duguid, 1954) and as the number of deaths from myocardial infarction between the ages of 45 and 49 years is five times greater in males (Registrar-General for Scotland, 1960). When the middle-aged cerebral cases are considered, it can be seen that there is a tendency for them to have higher fibrin levels and this is especially so of the females, but the differences are not statistically significant. However, the changes are such as to merit a more intensive study of this group.

Consideration of the fibrinolytic activity shows that once more there is an increase with age and also a positive correlation with fibrin levels. There is, however, within the limits of this pilot study, no interaction between sex and age and the differences are not statistically significant in any group between the sexes with regard to fibrinolytic activity. In view of the higher fibrin levels in the males compared with the females in middle life, it could be argued that the female has relatively more fibrinolytic activity with respect to fibrin than the male and possibly less susceptibility to thrombosis as a consequence of a greater clot-dissolving potentiality. It is interesting to note too that the lytic activity of the cerebral group as a whole is less than the controls and this applies especially to the males. The differences are not statistically significant but worthy of further investigation.

Finally, although the middle-aged cerebral group have only a relatively higher fibrin level and relatively lower fibrinolytic activity than their controls, when lysis during the second hour is expressed as a percentage of that of the first hour, it becomes apparent that the activity of the cerebral group has increased disproportionately. This could be explained by the presence of enhanced fibrinolytic inhibitor in those patients who have had cerebral vascular accidents. Antifibrinolytic activity has been described in cases of myocardial infarction (Guest et al., 1948).

I wish to thank Dr. A. Brown for his helpful advice and encouragement in the preparation of this paper. I am also indebted to Professor T. Ferguson Rodgers, Dr. L. D. W. Scott, and Dr. S. Lazarus for permission to investigate their patients, and to the Physiotherapy Department for facilitating some of the interviews. Mr. R. J. McGuire, of the Department of Psychological Medicine, kindly undertook the statistical analysis. My thanks are also due to the members of the hospital staff and students who volunteered to act as controls.

\section{REFERENCES}

Buckell, M., and Elliott, F. A. (1959). Lancet, 1, 660

Cohen, S. (1953). S. Afr. J. med. Sci., 18, 85.

Duguid, J. B. (1954). Lancet, 1, 891.

Gilchrist, E., and Tulloch, J. A. (1952). Edinb. med. J., 59, 561.

Greig, H. B. W., and Runde, I. A. (1957). Lancet, 2, 461.

Guest, M. M., Daly, B. M., Ware, A. G., and Seegers, W. H. (1948). J. clin. Invest., 27, 793.

Holborn, R. R. (1951). In Coagulation of the Blood. Methods of Study, ed. L.M. Tocantins. Grune and Stratton, New York and London.

Hume, R. (1958a). Brit. Heart J., 20, 15.

(1958b). Scot. med. J., 3, 479.

Janiakowa, A., Kotlarek-Haus, S., Potoczek, S., and Tkaczewski, W. (1958). Pol. Tyg. lek., 13, 921.

Nestel, P. J. (1959). Lancet, 2, 373.

Losner, S., Volk, B. W., and Wilensky, N. D. (1954). A.M.A. Arch. intern. Med., 93, 231.

Registrar-General for Scotland (1960). Annual Report, 1959. H.M.S.O., Edinburgh.

Røjel, J. (1959). Acta med. scand., 164, 81.

Schultz, F. H. (1956). In Experimental Research of Ageing, ed. F, Verzár, pp. 158, 181. (Experientia, Suppl. IV). Birk Lauser. Basel. 